\title{
KEPENTINGAN UMUM DALAM PERLINDUNGAN PATEN
}

\author{
Winner Sitorus \\ winsit66@yahoo.com \\ Fakultas Hukum Universitas Hasanuddin
}

\begin{abstract}
This article aimed at studying provisions in TRIPs Agreement and Law Number 14 of 2001 regarding Patent, particularly provisions reflecting criteria of public interest. The approach used is statutory and conceptual approaches by analysing TRIPS Agreement and Law Number 14 of 2001. It is concluded that public interest has been stipulated generally in TRIPs Agreement and Law Number 14 of 2001 in their provisions regarding kind and scope of the use of limitation and exception of patent holder's exclusive rights. Law Number 14 of 2001 basically has implemented limitation and exception provisions stipulated in TRIPS Agreement. However, it does not provide further and clearer elaborations on some provisions that need to be elaborated further. In addition, both TRIPs Agreement and Law Number 14 of 2001 do not provide criteria as to public interest.
\end{abstract}

Keywords: public interest, criteria, exception, limitation, patent.

\begin{abstract}
Abstrak
Artikel ini bertujuan untuk mempelajari ketentuan dalam TRIPs Agreement dan UndangUndang Nomor 14 Tahun 2001 tentang Paten, khususnya ketentuan yang mencerminkan kriteria kepentingan umum. Pendekatan yang digunakan adalah pendekatan hukum dan konseptual dengan menganalisis TRIPs Agreement dan Undang-Undang Nomor 14 Tahun 2001 tentang Paten. Hal ini menunjukkan bahwa kepentingan umum telah diatur secara umum dalam TRIPs Agreement dan Undang-Undang Nomor 14 Tahun 2001 dalam ketentuan mereka mengenai jenis dan ruang lingkup penggunaan pembatasan dan pengecualian hak eksklusif pemegang paten. Undang-Undang Nomor 14 Tahun 2001 tentang Paten pada dasarnya telah menerapkan pembatasan dan pengecualian ketentuan yang diatur dalam Perjanjian TRIPs; namun, rupanya hal itu tidak memberikan lebih lanjut dan elaborasi lebih jelas pada beberapa ketentuan yang perlu dijabarkan lebih lanjut. Selain itu, kedua TRIPs Agreement dan Undang-Undang Nomor 14 Tahun 2001 tentang Paten tidak memberikan kriteria untuk kepentingan umum.
\end{abstract}

Kata Kunci: paten, perjanjian TRIPs, hak eksklusif. 


\section{Pendahuluan}

Perlindungan terhadap karya intelektual manusia dalam bentuk Hak Kekayaan Intelektual (intellectual property right) ${ }^{1}$ - selanjutnya disingkat HKI - telah mendapat pengakuan dan pengaturan secara internasional dan nasional melalui konvensi-konvensi atau perjanjian-perjanjian internasional dan perundang-undangan nasional. Pemberian paten oleh negara, sebagai salah satu bentuk HKI, terhadap suatu invensi merupakan penghargaan terhadap inventor. ${ }^{2}$ Paten memberikan hak eksklusif bagi pemegang paten untuk jangka waktu tertentu melaksanakan sendiri invensinya tersebut atau memberikanpersetujuannya kepada pihak lain untuk melaksanakannya. ${ }^{3}$

Dalam perkembangannya, tidak dapat dipungkiri bahwa pemanfaatan dan penggunaan hak eksklusif oleh pemilik HKI, termasuk pemilik paten, telah menimbulkan persoalan-persoalan keadilan ekonomi dan konflik kepentingan, yang dapat menimbulkan tragedi anti-commons ${ }^{4}$ dan pada gilirannya dapat mengancam keberlanjutan hidup manusia. Kerangka hukum yang ada tampaknya kurang menjamin pemanfaatan dan penggunaan hak ekslusif yang adil dalam upaya untuk melindungi kepentingan umum. Persetujuan mengenai aspek-aspek HKI yang terkait Perdagangan atau TRIPs (Trade Related Aspects of Intellectual Property Rights), ${ }^{5}$ sebagai kerangka hukum pengaturan HKI secara internasional, kurang menjamin keseimbangan kepentingan perlindungan hak eksklusif pemilik HKI dan kepentingan umum, sehingga dalam praktiknya banyak menimbulkan masalah. ${ }^{6}$

Sifat eksklusif HKI sering digunakan atau ditempatkan melebihi atau di atas kepentingan umum yang justru merupakan dasar pembenaran atau justifikasi pemberian hak eksklusif tersebut. Ketidakkonsistenan ini disebabkan oleh yang disebut Peter Drahos seb-

1 Dalam Persetujuan TRIPs yang termasuk dalam lingkup HKI adalah Hak Cipta dan Hak yang Terkait, Merek, Indikasi Geografis, Desain Industri, Paten, Desain Tata Letak Sirkuit Terpadu, dan Undisclosed Information (Rahasia Dagang). Lihat Persetujuan TRIPs article 9-39.

2 Lihat Oentoeng Soerapati, Hukum Kekayaan Intelektual dan Alih Teknologi, UKSW, Salatiga: 1999, h.12. Lihat juga Gillian Davies and Kevin Garnett QC, Moral Rights, Thomson Reuters (Legal Limited), Sweet \& Maxwell, 2010.

3 Pasal 1 angka (1) Undang-Undang Nomor 14 Tahun 2001 tentang Paten (selanjutnya disingkat dengan UU No.14/2001).

4 Lihat Michael A. Heller, "The Tragedy of Anti Commons: Property in Transition From Marx to Markets, 111 Harv. L. Rev. 3 (1998).

5 TRIPs adalah salah satu Persetujuan yang dihasilkan dalam Putaran Uruguay di bawah naungan Organisasi Perdagangan Dunia (World Trade Organization - WTO) dibentuk pada tahun 1994 dan mengatur standar minimum perlindungan HKI. Indonesia telah meratifikasi Persetujuan Pembentukan Organisasi Perdagangan Dunia melalui UU No. 7 Tahun 1994. Lihat Michael Blakeney, "International intellectual property jurisprudence after TRIPs," dalam David Vaver and Lionel Bently, eds., Intellectual Property in the New Millennium Essays in Honour of William R. Cornish, New York: Cambridge University Press, 2004, h.3.

6 Deklarasi Doha tentang Perjanjian TRIPS dan Kesehatan Publik (Doha Ministerial Declaration on the TRIPS Agreement and Public Health) menegaskan bahwa Perjanjian TRIPS harus diinterpretasikan dan dilaksanakan dengan cara yang memungkinkan negara-negara untuk mengambil langkah-langkah melindungi kesehatan publik dan mengedepankan akses pada obat-obatan. Lihat Ministerial Conference, Fourth Session, Doha, 9-14 November 2001, WT/MIN(01)/DEC/2, 20November 2001. Lihat juga, Frederick M. Abbot, 'The Doha Declaration on the TRIPS Agreement and Public Health: Lighting a Dark Corner at the WTO,' http:// ssrn.com/abstract=1493725, diakses pada 5 Mei 2012. 
agai "the danger of inner logic" hak eksklusif. ${ }^{7}$ Eksploitasi hak eksklusif melalui HKI yang berlebihan dapat menimbulkan ketidakadilan sosial (social unjust). ${ }^{8}$ Terlepas dari ketentuanketentuannya yang ditujukan untuk melindungi kepentingan privat, ${ }^{9}$ TRIPs juga memberikan ruang untuk memberikan perlindungan terhadap kepentingan umum. Hanya saja makna dan kriteria kepentingan umum itu sendiri tidak diatur lebih lanjut dalam TRIPs, tetapi diserahkan kepada negara-negara anggota WTO. Dengan demikian, dapat terjadi multi-interpretasi terhadap makna kepentingan umum. Untuk menghindari multi-interpretasi terhadap makna kepentingan umum yang sulit untuk didefinisikan secara tepat tersebut dapat dilakukan dengan menemukan kriteria-kriteria dari kepentingan umum, dengan demikian mempermudah pembentukan aturannya. ${ }^{10}$ Dengan kriteria kepentingan umum yang tepat maka kepentingan umum dalam perlindungan paten tidak menjadikan negara bertindak sewenang-wenang terhadap pemegang paten dan sebaliknya kepentingan pihak-pihak lainnya tetap terlindungi. Oleh karena itu upaya untuk menemukan kriteria kepentingan umum dalam perundangundangan di bidang paten, baik yang berlaku secara internasional maupun nasional, perlu dilakukan.

\section{Justifikasi Kepentingan Umum dalam Perlindungan HKI}

Pertimbangan kepentingan umum dalam pemberian perlindungan paten memiliki dasar pembenaran secara normatif, konstitusionl, dan filosofis. Secara normatif, pertimbangan

7 Peter Drahos menggunakan frasa "the danger of inner logic" untuk menunjukkan paradoks dalam hak-hak eksklusif terhadap kebendaan (property). Dia mengacu pada sejarah adanya hak milik pribadi, yang menjadi dasar bagi hak-hak kebendaan, termasuk HKI. Drahos berpendapat bahwa adanya hak-hak pribadi atau hak-hak eksklusif adalah disetujui, didukung, dan disahkan secara suka rela oleh kesadaran publik. Dalam hal ini dukungan persetujuan atau dukungan publik telah membuka peluang-peluang baru bagi pemilik hak untuk mengeksploitasinya. Ketika peluang ini terkait dan dieksploitasi oleh kepentingan kapitalis atau kepentingan pribadi, tanpa batas, hal tersebut dapat mengancam kepentingan-kepentingan publik yang mendukung adanya hak-hak pribadi atau hak-hak eksklusif tersebut. Lihat Peter Drahos, A Philoshophy of Intellectual Property, Sydney: Dartmouth Publishing Company Limited, 1996, h. 119.

8 Jika negara-negara maju memiliki kepedulian terhadap negara-negara berkembang, maka sekitar sembilan juta orang di negara berkembang mungkin tidak harus mengalami kematian yang mengenaskan karena penyakit-penyakit menular. Hal ini terjadi karena tidak terjangkaunya harga obatan-obatan. Lihat Anupam Chander \& Madhavi Sunder, Is Nozick Kicking Rawls's Ass? Intellectual Property and Social Justice, UC Davis Legal Studies Research Paper Series Research Paper No. 108 May/2007, p. 567. http://ssrn.com/ abstract $=982981$. Sebagai perbandingan Maskus menyatakan bahwa: Perlindungan paten terhadap obatobatan tidak mendorong banyaknya penelitian dan pengembangan secara global untuk menemukan pengobatan atau vaksin bagi penyakit-penyakit endemik seperti malaria, tuberkolosis, dan AIDS di negara-negara miskin. Semua penelitian global untuk penanganan infeksi HIV ditujukan untuk orang-orang yang berada di negaranegara maju. Hampir tidak ada satupun yang ditujukan untuk penyakit endemik yang terjadi di negara-negara Pegurunan Selatan Afrika dan Asia Selatan, di mana terdapat banyak penyakit endemik tersebut. Baca Keith E. Maskus, Intellectual Property Rights in the Global Economy, Washington: Institute For International Economics, 2000, h.229.

9 Hal ini sebagaimana dinyatakan dalam konsiderans TRIPs yang menyatakan "Recognizingthat intellectual property rights are private rights".

10 Definisi dan hakikat kepentingan umum adalah bidang yang terus diperdebatkan di antara para ahli dan praktisi administrasi negara. Lihat King, Stephen.M, Bradley S. Chilton, and Gary E. Roberts, Reflection on Defining the Public Interest, http://m.aas.sagepub.com/content/41/8/954.abstract, diakses tanggal 21 Juli 2012. 
kepentingan umum telah diatur dalam konvensi-konvensi, perjanjian, dan perundangundangan di bidang paten. Secara konstitusional, kepentingan umum dapat dilihat dari tujuan negara. Sedangkan secara filosofis dapat dikaji dari pendapat-pendapat ahli mengenai prinsip keseimbangan hak dan kewajiban dan prinsip keadilan.

Secara internasional pertimbangan kepentingan umum dalam perlindungan paten telah diatur dalam Perjanjian TRIPs dan konvensi Paris (Paris Convention). Sementara secara nasional telah diatur UU No.14/2001. Dalam TRIPs kepentingan umum tercermin dalam Article 7 yang menentukan:

The protection and enforcement of intellectual property rights should contribute to the promotionof technological innovation and to the transfer and dissemination of technology, to the mutual advantageof producers and users of technological knowledge and in a manner conducive to social and economicwelfare, and to a balance of rights and obligations.

Article 7 ini menyiratkan adanya kepentingan umum melalui penekanan bahwa perlindungan dan penegakan HKI harus memberikan kontribusi terhadap alih teknologi dan penyebaran teknologi dengan memperhatikan kepentingan yang seimbang antara penghasil pengetahuan teknologi dan pengguna teknologi, dan dengan cara yang mendukung kesejahteraan sosial dan ekonomi dan menyeimbangkan hak dan kewajiban.

Berdasarkan Article 8 TRIPs negara-negara anggota WTO dimungkinkan dalam menyusun atau mengubah undang-undang dan peraturannya, untuk mengambil langkah-langkah yang diperlukan untuk melindungi kesehatan dan nutrisi publik, dan untuk mengedepankan kepentingan umum dalam sektor-sektor yang sangat penting bagi perkembangan sosial ekonomi dan teknologinya. Demikian pula dimungkinkan negara-negara anggota WTO untuk mengambil langkah-langkah yang patut untuk mencegah penyalahgunaan HKI oleh pemegang hak atau praktik-praktik yang yang dapat memengaruhi alih teknologi secara internasional. Namun semuanya itu harus dilakukan sesuai dengan ketentuan-ketentuan yang diatur dalam Perjanjian TRIPs. Terlepas bahwa semuanya harus dilakukan sesuai dengan ketentuan-ketentuan TRIPs lainnya, namun ketentuan ini merupakan pengakuan yang tegas terhadap hak-hak tiap negara anggota WTO untuk melindungi kepentingan umum dalam pengaturan HKI secara nasional.

Selain ketentuan TRIPs di atas, dalam Konvensi Paris juga diatur ketentuan-ketentuan pengecualian sebagai wujud kepentingan umum dalam perlindungan paten.Pertimbangan kepentingan umum juga terdapat dalam UU No.14/2001, walaupun undang-undang ini tidak menggunakan istilah kepentingan umum secara tegas tetapi menggunakan istilah kepentingan masyarakat pada umumnya. Hal ini sebagaimana dinyatakan dalam konsideran huruf b UU No.14/2001 bahwa yang diperlukan dalam rangka menciptakan iklim persaingan usaha yang jujur serta memperhatikan kepentingan masyarakat pada umumnya. Selanjutnya kepentingan umum atau kepentingan masyarakat pada umumnya dijabarkan dalam ketentuan pembatasan dan pengecualian. 
Kepentingan umum dalam perlindungan paten, sebagai bagian dari HKI, juga dapat dianalogkan dengan justifikasi kepentingan umum dalam hak milik karena pada dasarnya HKI, terlepas dari masih adanya perbedaan pendapat, telah diterima sebagai salah satu rezim hak milik. ${ }^{11}$ Dalam Undang-Undang Nomor 5 tahun 1960 tentang Peraturan Dasar Pokok-Pokok Agraria (selanjutnya disebut UU No.5/1960) pada Pasal 6 ditentukan, bahwa "Semua hak atas tanah mempunyai fungsi sosial". ${ }^{12}$ Selanjutnya dalam penjelasan Pasal 6 dinyatakan, bahwa:

hak atas tanah apapun yang ada pada seseorang, tidaklah dapat dibenarkan, bahwa tanahnya itu akan dipergunakan (atau tidak dipergunakan) semata-mata untuk kepentingan pribadinya, apalagi kalau hal itu menimbulkan kerugian bagi masyarakat. Penggunaan tanah harus disesuaikan dengan keadaannya dan sifat daripada haknya, hingga bermanfaat baik bagi kesejahteraan dan kebahagiaan yang mempunyainya maupun bermanfaat bagi masyarakat dan Negara. Tetapi dalam ketentuan tersebut tidak berarti, bahwa kepentingan perseorangan akan terdesak sama sekali oleh kepentingan umum (masyarakat).

Menurut Boedi Harsono, dari penjelasan pasal tersebut terdapat beberapa hal yang dapat diambil sebagai pemahaman bagaimana fungsi sosial tanah yang dimaksudkan dalam UU No.5/1960, antara lain: 1) Bahwa fungsi sosial tanah ini berlaku untuk semua hak atas tanah, baik hak milik, hak guna bangunan dan hak-hak lainnya; 2) Fungsi sosial dalam UU No. 5/1960 ini dimaknai bahwa dalam pemanfaatan tanah tidak semata-mata digunakan untuk kepentingan pribadi, apalagi merugikan masyarakat. Hal ini mengandung makna bahwa dalam penggunaan atau pemanfaatan tanah perlu adanya pengaturan yang menjamin terwujudnya kepentingan bersama; 3) Fungsi sosial tidak ditempatkan untuk menghilangkan kepentingan pemilik tanah tetapi harus ditempatkan sejajar. ${ }^{13}$

Dari penjelasan pasal dan uraian yang dikemukakan Boedi Harsono di atas jika dikaitkan dengan pemanfaatan HKI dapat dianalogkan bahwa pemanfaatan HKI oleh pemilik HKI tidak semata-mata digunakan untuk kepentingan pribadi, apalagi merugikan masyarakat. Oleh karenanya diperlukan pengaturan penggunaan HKI harus menjamin terwujudnya kepentingan bersama. Kepentingan umum dalam perlindungan HKI tidak menghilangkan kepentingan pemilik HKI tetapi harus ditempatkan sejajar.

Gagasan yang kurang lebih sama juga diatur dalam UU No.39/1999. Dalam Pasal 36 ditentukan, bahwa: 1) Setiap orang berhak mempunyai hak milik, baik sendiri maupun bersama-sama dengan orang lain demi pengembangan dirinya, keluarga, bangsa, dan masyarakat dengan cara yang tidak melanggar hukum; 2) Tidak seorangpun boleh dirampas

\footnotetext{
11 Lihat Winner Sitorus, Kepentingan Umum dalam Perlindungan Hak Kekayaan Intelektual (Kajian terhadap Hak Cipta, Paten, dan Perlindungan Varietas Tanaman), Disertasi, Program Doktor, Program Studi Ilmu Hukum, Fakultas Hukum Universitas Airlangga, 2014, h. 69-89.

12 Menurut penulis fungsi sosial adalah merupakan wujud kepentingan umum dalam penggunaan suatu hak atas benda.

13 Boedi Harsono, Hukum Agraria Indonesia, Sejarah Pembentukan Undang-Undang Pokok Agraria, Isi dan Pelaksanaannya, Jakarta: Djambatan, 2007, h. 296-304.
} 
miliknya dengan sewenang-wenang dan secara melawan hukum; 3) Hak milik mempunyai fungsi sosial.

Selanjutnya dalam penjelasan Pasal 36 Ayat (3), dikemukakan yang dimaksud dengan hak milik mempunyai fungsi sosial bahwa setiap penggunaan hak milik harus memperhatikan kepentingan umum. Apabila kepentingan umum menghendaki atau benarbenar membutuhkan maka hak milik dapat dicabut sesuai dengan ketentuan peraturan perundang-undangan. Jika ketentuan ini dikaitkan dengan HKI, maka hak eksklusif pemilik HKI sebagai wujud hak milik pribadi dalam penggunaannya dibatasi oleh kepentingan umum. Bahkan jika kepentingan umum menghendaki, sesuai dengan ketentuan peraturan perundang-undangan yang berlaku, hak eksklusif pemilik HKI dapat dicabut. ${ }^{14}$

Kepentingan umum juga mendapatkan landasan pembenarannya dari konstitusi ekonomi Indonesia, yaitu Undang-Undang Dasar 1945, yang pada dasarnya merupakan perwujudan dari nilai-nilai Pancasila. ${ }^{15}$ Sila-sila Pancasila terwujud dalam Pembukaan Undang-Undang Dasar 1945 yang memuat cita-cita utama negara, yaitu Negara yang didasarkan kepada Ketuhanan Yang Maha Esa berdasarkan kemanusiaan yang adil dan beradab, kedaulatan negara yang didasarkan kepada permusyawaratan perwakilan, negara mewujudkan keadilan sosial bagi seluruh rakyat Indonesia, dan negara melindungi seluruh rakyat Indonesia dan tumpah darah Indonesia berdasarkan persatuan. Oleh karena itu, Pancasila dan Pembukaan Undang-Undang Dasar 1945 dapat dipandang sebagai aksioma upaya-upaya hukum bagi Indonesia, antara lain untuk mengatur kekayaan intelektual, yang meliputi beberapa aspek, yaitu: tujuan hukum, sumber hukum, keadilan sosial, dan perlindungan hukum.

Tujuan negara yang pertama, yaitu negara berdasarkan KeTuhanan Yang Maha Esa berdasarkan kemanusiaan yang beradab di dalam bingkai negara kesatuan Indonesia, mengacu pada tujuan hukum yang mengatur kepentingan-kepentingan masyarakat atau yang menimbulkan hak dan kewajiban sebagaimana yang ditentukan oleh Tuhan. Dalam hal ini hubungan yang harmonis antara hak dan kewajiban adalah suatu keharusan, karenanya diperlukan perlindungan hukum. Hal ini memperlihatkan hubungan yang kuat antara moral dan hukum positif. Dalam hubungan yang demikian, hukum positif harus sesuai dengan moral. ${ }^{16}$ Hukum harus membantu manusia untuk mengembangkan

14 Istilah yang lazim digunakan dalam perundang-undangan HKI adalah pembatalan hak. Hal ini dapat dilihat dalam Undang-Undang Nomor 14 Tahun 2001 tentang Paten, Undang-Undang Nomor 15 tahun 2001 tentang Merek, Undang-Undang Nomor 29 Tahun 2000 tentang Perlindungan Varietas Tanaman, UndangUndang Nomor 31 Tahun 2000 tentang Desain Industri, dan Undang-Undang Nomor 32 tahun 2000 tentang Desain Tata Letak Sirkuit Terpadu.

15 Lihat hierarkhi peraturan perundang-undangan pada pasal 7 ayat (1) Undang-Undang Nomor 12 Tahun 2011

16 Menurut Thomas Aquinas hukum dapat mengandung ketidakadilan jika bertentangan dengan tujuan kesejahteraan publik. Dalam hal ini alasa moral harus merupakan alasan hukum, karena keduanya merupakan bagian dari kriteria yang fundamental bagi validitas hukum. Mereka meyakini bahwa terdapat hubungan yang esensial antara hukum dan moralitas. Lihat, Brian Leiter, Objectivity in Law and Morals, Cambridge University Press, 1999, h. 6. 
kehidupannya dan potensinya berdasarkan hakikatnya, yaitu dengan menjaga martabat manusia, mempertahankan keadilan, menjamin kesetaraan dan kebebasan, mengembangkan kepentingan umum, dan kesejahteraan umum. Ketidakadilan dalam hukum dapat timbul jika pemerintah melaksanakan hukum yang tidak mengandung kesejahteraan umum tetapi hanya kepentingannya sendiri, legislator membuat hukum malampaui kewenangannya, dan hukum yang dipaksakan pada masyarakat meskipun hukum itu didasarkan pada kesejahteraan umum. ${ }^{17}$

Tujuan yang kedua adalah negara yang berdaulat berdasarkan permusyawaratan perwakilan, mengacu pada sumber hukum yang mengandung karakteristik logika formal. Hal ini terwujud dalam bentuk negara sebagai organisasi kekuasaan rakyat dan demokrasi yang didasarkan pada musyawarah. Negara sebagai organisasi kekuasaan rakyat memilik hakhak dan kewajiban-kewajiban untuk mengatur produk-produk yang penting dan strategis, termasuk dalam pemanfaatan kekayaan intelektual untuk memenuhi kebutuhan individu, masyarakat dan negara. Negara memiliki kewenangan dan kedaulatan untuk mengambil kebijakan dan tindakan yang diperlukan untuk mewujudkan tujuan utama masyarakat. Oleh karena itu, untuk mencapai tujuan ini pemerintah harus memperhatikan demokrasi sebagai mekanisme negara dalam mengatur hak dan kewajiban. ${ }^{18}$

Tujuan ketiga, negara mewujudkan keadilan sosial bagi seluruh rakyat Indonesia mengacu pada keadilan sosial yang dapat mencakup lingkup keadilan yang luas, seperti keadilan distributif, keadilan komutatif, keadilan korektif, keadilan hukum, dan perlindungan kehidupan bersama. Keseimbangan antara hak dan kewajiban sebagaimana yang disebutkan dalam tujuan pertama adalah syarat utama untuk mencapai keadilan sosial. Namun demikian, pencapaiannya harus diwujudkan dalam cara yang tertib melalui cara-cara formal sebagaimana yang disebutkan dalam tujuan kedua.

Tujuan keempat, negara melindungi segenap bangsa Indonesia dan seluruh tumpah darah Indonesia berdasarkan persatuan mengacu pada aspek perlindungan hukum. Hal ini mengacu pada kewenangan negara dalam mengatur hak-hak yang berkaitan dengan kekayaan intelektual dan perlindungannya. Pemberian perlindungan hukum harus mencerminkan keadilan sebagaimana disebutkan dalam tujuan utama ketiga. Oleh karena itu perlindungan kreativitas dan produktivitas harus ditujukan pada pencapaian tujuan bersama tanpa mengorbankan kepentingan-kepentingan individu.

Berdasarkan keempat tujuan tersebut, negara harus melindungi eksistensi setiap pihak,

17 Lihat Thomas Aquinas, The Ends of Man, Summa Theologica dalam Lord Lloyd of Hampstead, Introduction to Jurisprudence, 3th ed, PraegerPublisher, 1972, h.96-97.

18 Mengikuti pendekatan yang dikemukakan oleh International Federation of Accountants - IFAC, mekanisme pengaturan hak dan kewajiban yang demokratis oleh negara dapat dilihat dalam prosesnya yang transparan, independen, sesuai prosedur yang benar, dan adanya partisipasi dari publik. Sejalan dengan prinsipprinsip utama Good Governance menurut Organization for Economic and Co-operation Development (OECD) yaitu akuntabilitas, transparansi, dan partisipasi. Lihat OECD, Accountability, Transparency, Participation: Key Elements of Good Governance, dalam http://www.oecd.org/gov/regulatory-policy/irrc.htm diakses tgl. 12 Juli 2012. 
sepanjang pihak-pihak yang terkait baik individu maupun kelompok mengakui keberadaan satu sama lain. Dalam konteks ini, semua tujuan-tujuan utama di atas dipandang sebagai indikator equity, keadilan, dan kebenaran. Dengan demikian, ketiganya dapat menjadi pertimbangan utama untuk melegitimasi kewenangan negara dalam mengatur pemberian, penggunaan, dan pemanfaatan kekayaan intelektual, baik bagi individu atau masyarakat.

Dari uraian di atas dapat ditarik suatu benang merah bahwa menurut cita-cita dan tujuan negara sebagaimana yang terdapat dalam Pembukaan UUD 1945, bahwa perlindungan hukum atas hak-hak yang dimiliki individu, termasuk atas HKInya, menimbulkan hak dan kewajiban. Namun perlindungan tersebut menyaratkan adanya keseimbangan hak dan kewajiban di dalam penggunaannya. Oleh karena itu negara perlu melakukan pengaturan terhadap pemanfaatan HKI yang dapat menjamin pemenuhan kepentingn individu, masyarakat, dan negara demi tercapainya tujuan bersama, yaitu keadilan sosial. Dengan demikian perlindungan terhadap kepentingan individu dilakukan tanpa mengabaikan kepentingan untuk pencapaian tujuan bersama.

Kepentingan umum dalam perlindungan HKI juga dapat dibenarkan berdasarkan prinsip keadilan. Pengaturan perlindungan HKI harus dilakukan secara adil yakni peraturan yang memberikan keseimbangan antara kepentingan-kepentingan manusia dan masyarakat yang dilindungi. ${ }^{19}$ Dalam konteks HKI dapat ditarik benang merah bahwa ketentuan perlindungan HKI harus memberi keseimbangan antara kepentingan pemilik HKI dan kepentingan masyarakat (kepentingan umum) agar terwujud keadilan.

Perlindungan HKI juga harus dapat menjamin keadilan dalam pendistribusian dan pemanfataan produk-produk HKI, terutama bagi pihak-pihak yang memiliki keterbatasan kemampuan dalam mengakses dan memanfaatkannya. Sejalan dengan itu prinsip keadilan dari John Rawls dapat dijadikan pembenaran.

Prinsip keadilan yang dikembangkan oleh John Rawls utamanya diterapkan pada struktur dasar masyarakat, mengatur pengalihan hak dan kewajiban, dan mengatur distribusi keuntungan-keuntungan ekonomi. ${ }^{20}$ John Rawls yang terkenal dengan teorinya justice as fairness, dimana di dalamnya juga terdapat konsep keadilan distributif (distributive justice), mengemukakan dua prinsip keadilan. Pertama prinsip greatest equal liberty, yaitu bahwa setiap orang mempunyai hak yang sama terhadap kebebasan dasar yang paling luas, seluas kebebasan yang sama bagi semua orang. Kedua, ketidaksamaan sosial dan ekonomi diatur sedemikian rupa sehingga diharapkan memberikan keuntungan bagi anggota masyarakat yang kurang beruntung difference principle) dan setiap posisi dan jabatan terbuka untuk semua pihak (principle of (fair) equality of opportunity). ${ }^{21}$

Rawls juga mengemukakan prioritas terhadap prinsip-prinsip keadilannya. Menurutnya, kebebasan individu yang sama (greatest equal liberty) lebih diutamakan dari

\footnotetext{
19 Van Apeldoorn, Pengantar Ilmu Hukum, Jakarta: Pradnya Paramita, 2001, h.11.

20 John Rawls, A Theory of Justice, Massachussets: Harvard University Press, 1999 h.5.

21 Ibid, h.53, 107, dan 266. Bandingkan Amartya Sen, The Idea of Justice, Penguin Book, 2009, h. 59.
} 
pada tuntutan-tuntutan prinsip kedua yang berkaitan kesamaan terhadap peluang bagi semua pihak dan kesamaan dalam distribusi sumber-sumber bagi semua pihak. ${ }^{22}$ Dalam hal prinsip kedua, di mana ada dua tuntutan di dalamnya, maka prinsip equality ofopportunity lebih diprioritaskan dari pada prinsip difference principle. ${ }^{23}$ Dengan kata lain, ketidaksamaan dapat dilakukan bila hal tersebut dapat memberi keuntungan kepada semua orang, terutama bagi mereka yang kurang beruntung (the least fortunatelleast advantage).

Prinsip keadilan John Rawls ini relevan sebagai dasar pembenaran dalam pemberian kesempatan yang sama untuk memperoleh hak milik, termasuk HKI di dalamnya. Hal ini menyangkut prinsip keadilan yang pertama dari John Rawls. Namun patut diingat bahwa dalam konteks dewasa ini, HKI telah menjadi sarana bagi pemiliknya (terutama perusahaan besar) sebagai aset untuk mencari keuntungan ekonomi yang sebesar-besarnya. Sejalan dengan itu, prinsip keadilan John Rawls yang kedua dapat diterapkan sebagai dasar pembenaran kepentingan umum dalam perlindungan HKI. Sistem HKI menjamin kebebasan setiap individu dalam memperolah HKI, namun demikian tetap harus memperhatikan kepentingan masyarakat, terutama masyarakat yang kurang beruntung yang tidak mungkin dapat bertahan hidup tanpa adanya perlakuan khusus. Berdasarkan teori keadilan Rawls, standardisasi dan harmonisasi perundang-undangan HKI yang didasarkan pada prinsip "one size fit all", tanpa mempertimbangkan ketidakseimbangan sosial dan ekonomi dapat dipandang sebagai ketidakadilan. ${ }^{24}$ Teori keadilan distributif Rawls sering disamakan juga teori keadilan sosial (social justice). ${ }^{25}$ Dalam konteks HKI, berdasarkan teori keadilan sosial Rawls, diperlukan keterlibatan negara yang lebih langsung untuk menata masyarakat yang lebih egaliter. Uraian di atas memperlihatkan betapa kepentingan umum dalam perlindungan HKI, termasuk paten, telah mendapatkan justifikasi yang kuat secara normatif, konstitusional, dan filosofis.

\section{Kriteria Kepentingan Umum}

Menentukan ukuran atau kriteria kepentingan umum sangatlah tidak mudah, karena kepentingan umum itu sendiri adalah konsep yang kabur sehinggal sulit untuk didefinisikan. Hal ini sebagaimana yang dikemukakan oleh Syafrudin Kalo bahwa masalah kepentingan umum secara konsepsional sangat sulit didefinisikan, terlebih-lebih kalau dilihat secara operasional. ${ }^{26}$ Demikian pula A.P. Parlindungan menyatakan bahwa ukuran kepentingan

22 Ibid, h. 266.

23 Ibid.

24 Hal ini sebagaimana yang dinyatakan oleh Peter Drahos bahwa standar Amerika Serikat adalah standar yang memenuhi kebutuhan ekonominya dan sesuai dengan tradisi budaya dan filosofisnya, tetapi standar itu bukanlah standar internasional. Lihat Peter Drahos, "Expanding Intellectual Property's Empire: the Roleof FTAs'," dalam www.bilaterals.org/IMG/doc/Expanding_IP_Empire_-_Role_of_FTAs.doc, h.14.

25 Istilah ini banyak digunakan oleh para penulis yang terdapat dalam Sudhir Anand, Fabiene Peter, and Amartya Sen (Editors), Public Health, Ethics, and Equity, Oxford University Press, 2004. Demikian juga Anupam Chander \& Madhavi Sunder, Loc.Cit.

26 Syafrudin Kalo, Pengadaan Tanah Bagi Pembangunan Untuk Kepentingan Umum, Jakarta: Pustaka Bangsa Press, 2004, h.69. 
umum sangatlah fleksibel sekali sehingga terlalu luas, dengan demikian jelas sulit untuk menjelaskan makna dari kepentingan umum. ${ }^{27}$

Agar kepentingan umum tidak berpeluang ditafsirkan sesuai kehendak pemerintah, diperlukan adanya kriteria yang harus dipatuhi oleh pemerintah dan dapat dipertanggungjawabkan secara hukum. Kriteria kepentingan umum yang baik dapat ditetapkan jika berpedoman pada syarat-syarat universal yang harus ada dalam kepentingan umum. Syarat yang utama dan mendasari semua syarat kepentingan umum adalah cita-cita dan tujuan negara yang telah diatur di dalam Pembukaan UUD 1945. Cita negara adalah mewujudkan rakyat, bangsa, dan negara yang merdeka, bersatu, berdaulat, adil dan makmur. Sedangkan yang menjadi tujuan negara adalah melindungi rakyat, segenap bangsa dan seluruh tumpah darah, memajukan kesejahteraan umum, dan mencerdaskan kehidupan bangsa. Cita dan tujuan negara tersebut menjadi penentu negara untuk mewujudkan keadilan, persatuan dan kesatuan, kemakmuran dan kesejahteraan rakyat serta melindungi seluruh rakyat Indonesia. ${ }^{28}$

Dari kajian yang ada yang didasarkan pada peraturan perundang-undangan yang berlaku, putusan pengadilan, dan pendapat ahli, terdapat beberapa kondisi yang dapat dijadikan acuan dalam menentukan kriteria kepentingan umum dalam perlindungan HKI, yaitu: ${ }^{29}$ a) Perlindungan di bidang kesehatan dan nutrisi publik; b) Pembangunan sosial ekonomi dan teknologi; c) Memperhatikan keseimbangan hak dan kewajiban antara pemilik HKI dan pengguna HKI; d) Tidak melanggar persaingan usaha; e) Penggunaan non-komersial; f) Untuk pendidikan, penelitian dan pengembangan, percobaan, dan ilmu pengetahuan; g) Untuk pertahanan dan keamanan; h) Untuk kebutuhan mendesak; i) Adanya remunerasi yang layak; j) Penggunaan oleh pemerintah; k) Ditetapkan melalui peraturan perundang-undangan oleh pemerintah (intervensi negara).

Dari beberapa kondisi di atas dapat ditentukan kriteria kepentingan umum dalam perlindungan HKI, yaitu adanya intervensi negara melalui peraturan perundanganundangan, peruntukan HKI (bagi masyarakat, negara, dan persaingan usaha yang sehat), dan adanya pemberian remunerasi yang layak bagi pemilik HKI. Kriteria kepentingan umum di atas memiliki kekuatan mengikat secara hukum jika telah dinyatakan dan diatur dalam peraturan perundang-undangan dan dapat menjadi pedoman bagi hakim dalam memutuskan suatu sengketa yang berkaitan dengan kepentingan umum dalam pemanfataan kekayaan intelektual. Dalam praktik pengaturan di bidang HKI secara internasional maupun nasional -khususnya yang berkaitan dengan Paten- pada umumnya kriteria kepentingan umum diwujudkan ke dalam ketentuan-ketentuan pembatasan dan pengecualian. Namun demikian, di luar ketentuan pembatasan dan pengecualian, tidak jarang pula dijumpai ketentuanketentuan yang merupakan perwujudan dari ketentuan umum.

27 A.P. Parlindungan, Bunga Rampai Hukum Agraria Serta Landeform, Bagian I, Bandung: Mandar Maju, 1994, h. 64.

28 Lihat pembahasan justifikasi kepentingan umum di atas.

29 Winner Sitorus, Op.Cit., h.173-174. 


\section{Kriteria Kepentingan Umum Dalam Perlindungan Paten}

Kriteria kepentingan umum dalam perlindungan paten pada dasarnya dapat diabstraksikan dari ketentuan-ketentuan Konvensi Paris, Persetujuan TRIPs, dan UU No.14/2001. Oleh karena UU No.14/2001 pada dasarnya merupakan implementasi dari Konvensi Paris dan Persetujuan TRIPs, pembahasan artikel ini hanya menitikberatkan pada ketentuan-ketentuan UU No.14/2001 yang mencerminkan kriteria kepentingan umum dalam perlindungan paten.

Kriteria kepentingan umum dalam perlindungan paten yang terdapat dalam UU No.14/2001 tercermin dalam ketentuan-ketentuan pembatasan dan pengecualian dan beberapa ketentuan lainnya. Pertama, dalam Pasal 7 UU No. 14/2001 ditentukan bahwa Paten tidak diberikan untuk Invensi yang terkait dengan proses atau produk yang pengumuman dan penggunaan atau pelaksanaannya bertentangan dengan peraturan perundang-undangan yang berlaku, moralitas agama, ketertiban umum, atau kesusilaan; metode pemeriksaan, perawatan, pengobatan dan/atau pembedahan yang diterapkan terhadap manusia dan/atau hewan; teori dan metode di bidang ilmu pengetahuan dan matematika; atau semua makhluk hidup, kecuali jasad renik; proses biologis yang esensial untuk memproduksi tanaman atau hewan, kecuali proses non-biologis atau proses mikrobiologis.

Ketentuan Pasal 7 UU No. 14/2001 pada dasarnya sesuai dan sejalan dengan ketentuan yang diatur dalam Article27 (2) Perjanjian TRIPs. Secara substansial tidak ada permasalahan dengan pembatasan ini. Namun yang menjadi persoalan adalah apa yang dimaksud dengan bertentangan dengan peraturan perundang-undangan yang berlaku. Tidak ada penjelasan lebih lanjut mengenai kata-kata tersebut. Berbeda halnya dengan di Australia, walaupun tidak ada pengertian di dalam perundang-undangan tentang kata bertentangan dengan perundang-undangan yang berlaku, hal tersebut diatur dalam Buku Pedoman Pemeriksa. Bahkan di samping memberikan pengertian dan penjelasan tentang hal tersebut, Buku Pedoman Pemeriksa juga memberikan contoh-contoh invensi yang dikategorikan sebagai "bertentangan dengan perundang-undangan". ${ }^{30}$ Dengan tidak adanya penjelasan atau buku pedoman, penentuan apakah invensi bertentangan dengan perundang-undangan yang berlaku dapat dilihat melalui spesifikasi dan klaim tertulis yang diajukan. Persoalan pengertian "bertentangan dengan peraturan perundang-undangan yang berlaku" di atas juga sama halnya dalam menentukan pengertian kata "ketertiban umum" dan "moralitas agama". Hal ini juga tidak diberikan pengertian dalam UU No. 14/2001 maupun penjelasannya. Dengan demikian penentuan makna kata-kata tersebut bergantung pada penafsiran pegawai Kantor Paten dan hakim niaga.

Dengan tidak adanya Buku Pedoman atau bentuk lainnya, maka pegawai Kantor Paten dan hakim niaga akan mengalami kesulitan dalam menafsirkan makna kata-kata

${ }^{30}$ Nurul Barizah, Intellectual Property Implications on Biological Resources Indonesia's Adoption of International Intellectual Property Regimes and the Failure to Adequately address the Policy Challenges in the Area of Biological Resources, Jakarta: Nagara, 2010, h.260. 
tersebut. Untuk mengatasi hal tersebut sebaiknya pemerintah Indonesia mengeluarkan peraturan pemerintah atau buku pedoman yang dapat menjadi pedoman dalam menentukan dan mengklasifikasi jenis invensi yang dipandang bertentangan dengan peraturan perundangundangan yang berlaku, moralitas agama, dan ketertiban umum. ${ }^{31}$ Pemerintah Indonesia dapat mengadopsi makna ketertiban umum yang digunakan oleh Kantor Paten Eropa dan Article 27 (2) yaitu ketertiban umum dalam kaitannya dengan paten adalah kondisi yang berkaitan dengan keamanan dan perlindungan terhadap manusia, kehidupan hewan dan tanaman, dan lingkungan. Oleh karena itu invensi-invensi yang dapat menimbulkan kerusuhan atau kekacauan, tindakan kriminal, dan membahayakan kehidupan manusia, hewan dan tanaman, kesehatan dan merusak lingkungan tidak dapat diberikan paten.

Persoalan lain yang terkait dengan ketentuan Pasal 7 UU No. 14/2001 adalah tidak dapat dipatenkannya invensi yang terkait makhluk hidup, termasuk manusia, hewan atau tanaman. Dalam Memori Penjelasan Umum UU No. 14/2001, dijelaskan bahwa ketentuan yang diatur dalam Pasal 7 huruf d dimaksudkan untuk mengakomodasi usulan masyarakat agar bagi Invensi tentang makhluk hidup (yang mencakup manusia, hewan, atau tanaman) tidak dapat diberi Paten. Sikap tidak dapat dipatenkannya Invensi tentang manusia karena hal itu bertentangan dengan moralitas agama, etika, atau kesusilaan. Di samping itu, makhluk hidup mempunyai sifat dapat mereplikasi dirinya sendiri. ${ }^{32}$

Pertanyaan yang dapat muncul dari ketentuan di atas, adalah apakah invensi yang terkait dengan bagian dari makhluk hidup, misalnya gen dapat dipatenkan. Jika membaca ketentuan Pasal 7 huruf d (i) UU No. 14/2001 di atas dapat ditafsirkan bahwa yang dikecualikan dari dapat dipatenkannya suatu invensi adalah manusia, binatang, atau tanaman secara keseluruhan. Dengan demikian, jika hanya bagian dari makhluk hidup itu maka dapat diberikan paten. ${ }^{33}$ Jadi invensi yang terkait dengan gen dapat dipatenkan, demikian pula bagian dari tanaman dalam bentuk varietas tanaman dapat dilindungi melalui Perlindungan Varietas. Jika penafsiran ini dapat diterima, maka akan menimbulkan persoalan terkait dengan nilai-nilai moral dan agama yang berlaku. ${ }^{34}$

Substansi ketentuan Pasal 7 huruf d (i) UU No. 14/2001 ini patut mendapat perhatian. Hal ini disebabkan karena isu-isu yang berkaitan dengan perkembangan bioteknologi mempunyai kemungkinan yang besar menimbulkan pertentangan dan ketidaktenangan publik, yang dapat melanggar hukum yang berlaku, ketertiban umum, dan moralitas, yang merupakan alasan penolakan untuk dapat dipatenkannya invensi-invensi tertentu. Di sisi lain tidak ada kepastian mengenai pengertian dan lingkup istilah-istilah peraturan perundangundangan, ketertiban umum dan moralitas agama. Pada prinsipnya, mempertimbangkan dan memasukkan kriteria martabat manusia dalam wacana paten tidak melampaui peranan

\footnotetext{
31 Ibid, h.261.

32 Ibid, h. 264.

33 Ibid, h. 265.

34 Ibid.
} 
negara. Oleh karena itu pendekatan kemanusiaan dapat mengarah pada suatu pembatasan yang signifikan terhadap hukum paten. Pendekatan kemanusiaan ditunjukkan melalui penitikberatan pada perlindungan dan pemeliharaan martabat manusia. Hal ini menyaratkan agar objek perlindungan hukum paten dibatasi ketika terkait dengan martabat manusia dan invensi yang diajukan untuk perlindungan paten ditolak jika tidak sesuai dengan martabat yang melekat pada diri manusia. Oleh karena itu ketentuan Pasal 7 d (i) UU No. 14/2001 seyogyanya diamandemen.

Undang-undang Paten Indonesia harus berani menentukan secara tegas bahwa gen atau DNA manusia tidak dapat dipatenkan, dengan pertimbangan teknis ${ }^{35}$ karena makhluk hidup mempunyai sifat dapat mereplikasi dirinya sendiri dan pertimbangan nilai moral dan agama yang berlaku di Indonesia.Pandangan ini mempunyai dasar yang cukup kuat dengan melihat perkembangan dapat dipatenkannya gen di Amerika Serikat yang menimbulkan perdebatan dan pendapat yang berbeda-beda dalam putusan pengadilan dalam hal teknis. ${ }^{36}$

Dari uraian di atas terlepas dari masih adanya kekurangjelasan dalam ketentuan Pasal 7 UU No. 14/2001, namun secara keseluruhan ketentuan pasal ini dapat dijadikan dasar untuk perlindungan kepentingan umum. Ketentuan ini pada dasarnya merupakan perwujudan penghargaan terhadap moralitas dan martabat manusia. Dalam kaitannya dengan kriteria kepentingan umum, ketentuan ini secara tidak langsung berkaitan dengan kriteria intervensi negara.

Kedua, adalah ketentuan Pasal 16 Ayat (3) UU No. 14/2001. Ketentuan pasal tersebut menyatakan bukan pelanggaran terhadap hak eksklusif pemegang paten pemakaian paten untuk kepentingan pendidikan, penelitian, percobaan, atau analisis sepanjang tidak merugikan kepentingan yang wajar dari Pemegang Paten. Ketentuan in dimaksudkan untuk memberikan kesempatan bagi pihak yang betul-betul memerlukan penggunaan Invensi semata-mata untuk penelitian dan pendidikan. ${ }^{37}$ Pengaturan pembatasan dengan alasan untuk tujuan pendidikan, penelitian, dan percobaan ini adalah sejalan dengan ketentuan Article 30 TRIPs, seperti yang telah dibahas sebelumnya. Ketentuan ini juga secara tidak langsung mencerminkan adanya pengakuan terhadap hak asasi manusia dalam hal akses terhadap informasi dari sisi pengguna paten, dan perlindungan hak milik (paten) dari sisi pemegang paten. Dengan demikian ketentuan ini secara tidak langsung mencerminkan kriteria kepentingan umum dalam hal peruntukan HKI bagi masyarakat.

Ketiga, adalah ketentuan Pasal 42-47 UU No. 14/2001 tentang pengumuman. Ditentukan bahwa adanya permohonan paten diumumkan dalam Berita Resmi Paten yang diterbitkan secara berkala oleh Direktorat Jenderal dan/atau menempatkannya pada

35 Lihat Peter Drahos, “Capitalism, Efficiency and Self-Ownership”, 28 Austl. J. Leg. Phil, 2003, h. 215.

36 Dalam kasus Ass'n for Molecular Pathology v. U.S. Patent \&Trademark Office, 702 F. Supp. 2d181, 184 (S.D.N.Y. 2010), Judge Sweet membuat kaget komunitas paten melalui putusannya yang menolak ribuan paten gen yang telah dikeluarkan oleh USPTO (United States Patent and Trademark Office) selama tiga dasawarsa.

37 Penjelasan Pasal 16 (3) UU No. 14/2001. 
sarana khusus yang disediakan oleh Direktorat Jenderal yang dengan mudah serta jelas dapat dilihat oleh masyarakat (Pasal 43 UU No. 14/2001). Dengan adanya pengumuman yang mudah dan jelas dapat dilihat oleh masyarakat ini, maka setiap pihak dapat melihatnya dan dapat mengajukan secara tertulis pandangan dan/atau keberatannya atas Permohonan yang bersangkutan dengan mencantumkan alasannya. (Pasal 45 UU No. 14/2001). Jika ada keberatan atas permohonan paten setelah adanya pengumuman, Direktorat Jenderal menggunakan pandangan dan/atau keberatan, sanggahan, dan/ataupenjelasan tersebut sebagai tambahan bahanpertimbangan dalam tahap pemeriksaan substantif (Pasal 5 Ayat (4) UU No. 14/2001). Ketentuan ini secara tidak langsung melindungi kepentingan umum dalam hal untuk mencegah dilindunginya invensi yang mungkin telah dimiliki oleh orang lain, atau diajukan oleh pihak yang tidak berwenang. Jika dikaitkan dengan kriteria kepentingan umum, secarat tidak langsung kriteria ini mencerminkan kriteria peruntukan HKI bagi masyarakat dan tidak anti persaingan.

Keempat, adalah ketentuan Pasal 71 Ayat (1) UU No. 14/2001 yang mengatur mengenai isi perjanjian lisensi. Ketentuan pasal tersebut menyaratkan bahwa perjanjian lisensi tidak boleh memuat ketentuan, baik langsung maupun tidak langsung, yangdapat merugikan perekonomian Indonesia atau memuat pembatasan yang menghambatkemampuan bangsa Indonesia dalam menguasai dan mengembangkan teknologi padaumumnya dan yang berkaitan dengan invensi yang diberi paten tersebut pada khususnya.Ketentuan ini sangat luas rumusannya, baik dari sisi kepastian hukum untuk alih teknologi melalui Perjanjian Lisensi, maupun perlindungan kepentingan umum melalui pembatasan terhadap isi Perjanjian Lisensi.

Melihat isi ketentuan Pasal 71 UU No. 14/2001, tampaknya pasal ini dimaksudkan untuk mengatur praktik dagang yang curang atau persaingan usaha yang tidak sehat. Namun sangat disayangkan karena tidak diatur secara detail, ketentuan ini dapat menimbulkan penafsiran yang luas. Terlebih lagi dalam Penjelasan Pasal 71 UU No. 14/2001 dinyatakan cukup jelas. Dengan demikian memberikan ruang yang besar bagi Hakim untuk menafsirkannya jika terjadi sengketa dengan Perjanjian Lisensi di kemudian hari. Ketentuan ini seyogianya diperjelas dan dipertegas dalam hal pembatasan-pembatasan terhadap substansi Perjanjian Lisensi sehingga memberikan kepastian hukum dalam pemanfaatan teknologi dan perlindungan kepentingan umum. ${ }^{38}$ Kepastian hukum diperlukan untuk menciptakan situasi yang kondusif tidak hanya untuk bisnis yang sehat tetapi juga untuk

38 Sebagai perbandingan, di Australia lisensi paten diatur dalam the Patents Act 1990 and the TradePractice Act 1974 secara terinci. Bahkan di Amerika Serikat pemerintah mengatur pemberian lisensi melalui beberapa sarana hukum, yaitu: Hukum Persaingan (hukum federal), Hukum Penyalahgunaan/Misuse Law (yang berkaitan dengan beberapa perundang-undangan kekayaan intelektual), Doktrin Ketertiban Umum/ Public Policy, dan doktrin pre-emption yaitu doktrin konstitusional untuk melindungi perundang-perundangan pemerintah federal dari campur tangan perundang-undangan negara bagian. Lihat, John W.Schlicher,Licensing Intellectual Property: Legal, Business and Market Dynamics, Wiley Intellectual Property Series, John Wiley \& Sons, Inc, 1996, h. xxvii. 
melindungi kepentingan umum. Jika tidak, hal ini merugikan setiap pihak, termasuk investor asing dalam memanfaatkan patennya melalui perjanjian lisensi. Kejelasan ini penting, terlebih karena Undang-Undang Persaingan Usaha justru mengecualikan perjanjian lisensi dari perjanjian-perjanjian yang dilarang. ${ }^{39}$

Namun terlepas dari rumusannya yang umum dan kurang jelas, ketentuan ini merupakan wujud kepentingan umum karena mencegah penyalahgunaan hak oleh pemegang hak eksklusif terhadap pengguna HKI, yang pada gilirannya akan berdampak pada konsumen dan negara. Pasal ini mencerminkan kriteria kepentingan umum dalam hal peruntukan HKI yang tidak bertentangan dengan persaingan usaha yang sehat dan intervensi negara.

Kelima, adalah ketentuan Pasal 74-87 UU No. 14/2001 yang mengatur tentang Lisensi Wajib. Yang dimaksud dengan lisensi wajib adalah lisensi untuk melaksanakan Paten yang diberikan berdasarkan keputusan Direktorat Jenderal atas dasar permohonan (Pasal 74 UU No. 14/2001). Untuk dapat diberikan lisensi wajib harus memenuhi beberapa persyaratan, yaitu: Paten yang bersangkutan tidak dilaksanakan atau dilaksanakan tidak sepenuhnya di Indonesia oleh Pemegang Paten. (Pasal 75 Ayat (2) UU No. 14/2001); paten telah dilaksanakan oleh Pemegang Paten atau Penerima Lisensi dalam bentuk dan dengan cara yang merugikan kepentingan masyarakat (Pasal 75 Ayat (3) UU No. 14/2001).

Ketentuan Pasal 75 Ayat (3) UU No. 14/2001 ini juga terkait dengan Pasal 91 huruf c UU No. 14/2001, yang menentukan bahwa jika dalam jangka waktu dua tahun setelah lisensi wajib diberikan, keberadaan lisensi wajib tersebut ternyata tidak mampu mencegah berlangsungnya pelaksanaan Paten dalam bentuk dan cara yang merugikan kepentingan masyarakat, paten tersebut dimintakan pembatalan melalui gugatan. Di samping persyaratan di atas, pemohon juga harus memenuhi persyaratan lain, yaitu: ${ }^{40}$ mempunyai kemampuan untuk melaksanakan sendiri Paten yang bersangkutan secara penuh; mempunyai sendiri fasilitas untuk melaksanakan Paten yang bersangkutan dengan secepatnya; dan telah berusaha mengambil langkah-langkah dalam jangka waktu yang cukup untuk mendapatkan Lisensi dari Pemegang Paten atas dasar persyaratan dan kondisi yang wajar, tetapi tidak memperoleh hasil; dan Direktorat Jenderal berpendapat bahwa Paten tersebut dapat dilaksanakan di Indonesia dalam skala ekonomi yang layak dan dapat memberikan manfaat kepada sebagian besar masyarakat. Selanjutnya ditentukan bahwa, ketentuan lebih lanjut mengenai lisensi wajib akan diatur melalui peraturan pemerintah. ${ }^{41}$

Ketentuan-ketentuan UU No.14/2001 tentang lisensi wajib tersebut mencerminkan kepentingan umum dalam perlindungan paten. Dari alasan-alasan yang dikemukakan untuk pemberian lisensi wajib tersebut tercermin kriteria kepentingan umum dalam hal peruntukan

\footnotetext{
39 Lihat Pasal 50 huruf b Undang-Undang Nomor 5 Tahun 1999 tentang Larangan Praktik Monopoli dan Persaingan Usaha Tidak Sehat (Lembaran Negara Republik Indonesia Tahun 1999 Nomor 33, Tambahan Lembaran Negara Republik Indonesia Nomor 3817).

40 Pasal 76 UU No. 14/2001.

41 Pasal 87 UU No. 14/2001.
} 
HKI bagi masyarakat, negara, dan tidak bertentangan dengan persaingan usaha yang sehat, remunerasi yang layak, dan intervensi negara.

Keenam, adalah ketentuan Pasal 99 UU No. 14/2001 yang mengatur tentang Pelaksanaan Paten oleh Pemerintah. Ditentukan bahwa pemerintah dapat melaksanakan sendiri suatu paten apabila Pemerintah berpendapat bahwa suatu Paten di Indonesia sangat penting artinya bagi pertahanan keamanan Negara dan terdapat kebutuhan sangat mendesak untuk kepentingan masyarakat. Kebutuhan sangat mendesak untuk kepentingan nasional mencakup, antara lain bidang kesehatan seperti obat-obatan yang masih dilindungi Paten di Indonesia yang diperlukan untuk menanggulangi penyakit yang berjangkit secara luas (endemi). Demikian juga dalam bidang pertanian, misalnya pestisida yang sangat dibutuhkan untuk menanggulangi gagalnya hasil panen secara nasional yang disebabkan oleh hama. Sebagaimana diketahui, salah satu fungsi suatu Paten adalah untuk menjamin kelangsungan hidup perekonomian negara serta mengupayakan makin meningkatnya kesejahteraan masyarakat di negara yang bersangkutan. ${ }^{42}$

Ketentuan lebih lanjut mengenai pelaksanaan paten oleh pemerintah ini diatur lebih lanjut melalui Peraturan Pemerintah Nomor 27 Tahun 2004 tentang Tata Cara Pelaksanaan Paten oleh Pemerintah. ${ }^{43}$ Peraturan Pemerintah ini kemudian ditindaklanjuti dengan Keputusan Presiden Nomor 83 Tahun 2004 tentang Penggunaan Paten oleh Pemerintah terhadap Obat-obat Anti-Retroviral, ${ }^{44}$ yang dalam perkembangannya kemudian diganti dengan Keputusan Presiden Nomor 27 Tahun 2007 tentang Perubahan Atas Keputusan Presiden Nomor 83 Tahun 2004, dan terakhir diganti dengan Peraturan Presiden Nomor 76 Tahun 2012 tentang Pelaksanaan Paten oleh Pemerintah Terhadap Obat Antiviral dan Antiretroviral. Pertimbangan dari dikeluarkannya Peraturan Presiden Nomor 76 Tahun 2012 ini adalah berkaitan dengan adanya kebutuhan yang sangatmendesak dalam upaya penanggulangan penyakit Human Immunodeficiency Virus-Acquired Immuno Deficiency Syndrome (HIV/AIDS) dan Hepatitis B diIndonesia sehingga diperlukan untuk melanjutkan dan memperluas kebijakanakses memberikan akses terhadap obat Antiviral dan Antiretroviral yang saat ini masih dilindungi Paten.

Dengan adanya pelaksanaan paten oleh pemerintah ini, yang sebenarnya merupakan

42 Penjelasan Pasal 99 Ayat (1) UU No. 14/2001.

43 Dalam Pasal 3 Peraturan Pemerintah Nomor 27 Tahun 2004 ditentukan bahwa pelaksanaan paten oleh Pemerintah dalam hal sangat penting bagi pertahanan dan keamanan negara meliputi bidang senjata api, amunisi, bahan peledak militer, senjata kimia, senjata biologi, senjata nuklir, dan perlengkapan militer. Sedangkan dalam hal kebutuhan yang sangat mendesak untuk kepentingan masyarakat dari suatu Paten diatur dalam Pasal 4, yang meliputi bidang produk farmasi yang diperlukan untuk menanggulangi penyakit yang berjangkit secara luas, produk kimia yang berkaitan dengan pertanian, atau obat hewan yang diperlukan untuk menanggulangi hama dan penyakit hewan yang berjangkit secara luas.

${ }_{44}$ Keputusan Presiden ini menjadi dasar pelaksanaan paten oleh pemerintah untuk memproduksi dua jenis obat generik untuk penderita HIV-AIDS, yaitu lamivudine dan nevirapine sampai akhir masa perlindungan paten yaitu pada tahun 2011 dan 2012. Lisensi ini disertai dengan pembayaran royalti 0,5 persen dari nilai penjualan bersih. Produksi obat-obatan antiretroviral ini dilaksanakan oleh PT.Kimia Farma. Lihat James Packard Love, Op.Cit., h.12. 
wujud lain dari lisensi wajib, maka pemerintah memungkinkan diproduksinya tujuh jenis obat-obatan generik yang sangat penting dalam pengobatan HIV dan Hepatitis B. Dengan langkah ini akan menjamin sekitar 310.000 orang yang hidup dengan HIV di Indonesia untuk bisa memiliki akses terhadap obat-obatan penting penyambung nyawa mereka. ${ }^{45}$ Tentunya pelaksanaan paten oleh pemerintah ini tidak hanya terbatas pada Obat antiviral dan antiretroviral saja, tetapi juga dapat dilakukan terhadap obat-obatan penting lainnya, misalnya obat Tamiflu untuk flu burung (avian influenza). Lisensi wajib melalui penggunaan oleh pemerintah ini, tidak hanya dilakukan oleh pemerintah Indonesai tetapi juga oleh beberapa negara di berbagai belahan dunia, antara lain Malasyia yang mengimpor didanosine (ddI),zidovudine (AZT) and lamivudine+zidovidine (combivir) dari India, Taiwan yang menggunakan lisensi wajib untuk memproduksi dan menjual versi generik dari Tamiflu, Thailand yang mengimpor dari India dan memproduksi efavirenz secara lokal. ${ }^{46}$

Ketentuan-ketentuan di atas mencerminkan kepentingan umum dalam hal pengakuan terhadap hak asasi manusia atas kesehatan dan makanan dari sisi orang-orang yang membutuhkan obat dan makanan dan pengakuan terhadap hak milik (paten) dari sisi pemegang paten. Dalam kaitannya dengan kriteria kepentingan umum, ketentuan ini mencerminkan kriteria peruntukan HKI bagi masyarakat dan negara, serta adanya intervensi negara.

Ketujuh adalah ketentuan Pasal 135 UU No. 14/2001. Dalam pasal ini ditentukan dua alasan pengecualian terhadap tuntutan pidana terhadap pelanggaran paten. Pertama adalah terkait dengan impor paralel produk farmasi (obat-obatan). ${ }^{47}$ Tujuannya adalah untuk menjamin adanya harga yang wajar dan memenuhi rasa keadilan dari produk farmasi yang sangat dibutuhkan bagi kesehatan manusia. Ketentuan ini dapat digunakan apabila harga suatu produk di Indonesia sangat mahal dibandingkan dengan harga yang telah beredar secara sah di pasar internasional. ${ }^{48}$ Kedua adalah memproduksi produk farmasi yang dilindungi Paten di Indonesia dalam jangka waktu 2 (dua) tahun sebelum berakhirnya perlindungan Paten dengan tujuan untuk proses perizinan kemudian melakukan pemasaran setelah perlindungan Paten tersebut berakhir. ${ }^{49}$ Tujuan pengecualian ini adalah untuk menjamin tersedianya produk farmasi oleh pihak lain setelah berakhirnya masa perlindungan Paten. Dengan demikian, harga produk farmasi yang wajar dapat diupayakan.

Namun demikian, adanya ketentuan Pasal 135 UU No. 14/2001 tidak berarti UU 14/2001 membolehkan impor paralel terhadap produk farmasi yang dilindungi paten. Karena

45 Buletin Pusat data dan Informasi PERSI, "RI Bisa Jadi Contoh Pengaturan Lisensi Wajib Obat Penting”, 15-10-2012, dalam http://www.pdpersi.co.id/content/news.php?catid=23\&mid=5\&nid=953 diunduh 12 Desember 2012.

46 Untuk contoh penggunaan lisensi wajib dan penggunaan oleh pemerintah di negara-negara maju dan negara berkembang dapat dilihat pada James Packard Love.

47 Pasal 135 huruf a UU No. 14/2001.

48 Penjelasan Pasal 135 UU No. 14/2001.

49 Pasal 135 huruf b UU No. 14/2001. 
dalam Pasal 130 ditentukan bahwa impor paralel adalah pelanggaran pidana. Ketentuan tersebut hanya mengecualikan dari tuntutan pidana sebagaimana yang diatur dalam Pasal 130 UU No. 14/2001, tetapi tidak menghilangkan hak pemegang paten untuk menuntut ganti kerugian berdasarkan ketentuan Pasal 118 UU No. 14/2001, yang memberikan hak kepada pemegang paten atau penerima lisensi untuk mengajukan gugatan ganti rugi kepada Pengadilan Niaga terhadap tindakan impor paralel. ${ }^{50}$ Dengan demikian, akibatnya tujuan Indonesia untuk mempermudah pengimporan paralel produk-produk farmasi, sebagaimana disebutkan dalam Penjelasan Pasal 135 huruf a UU No. 14/2001 di atas, dapat terhalang oleh ketentuan Pasal 118 ayat (1) UU No. 14/2001 tersebut. ${ }^{51}$

Melihat ketentuan-ketentuan di atas, seyogianya Indonesia tidak hanya mengecualikan impor paralel dari sanksi pidana, tetapi harus membuat hak importasi pemegang hak berakhir setelah penjualan pertama terhadap produk-produk farmasi. Hal ini didasarkan pada beberapa pertimbangan. ${ }^{52}$ Kedelapan adalah ketentuan mengenai persyaratan substantif perlindungan paten (patentable subject matter) yang diatur dalam Pasal 2 Ayat (1) UU No. 14/2001 yang menentukan bahwa paten diberikan untuk Invensi yang baru dan mengandung langkah inventif serta dapatditerapkan dalam industri. Hanya invensi yang memenuhi tiga persyaratan tersebut yang dapat diberikan paten, sepanjang tidak bertentangan dengan ketentuan Pasal 7 UU No. 14/2001. Ketentuan ini mencerminkan kepentingan umum dalam hal domain publik. Hanya invensi yang dapat menambah dan bukan mengurangi domain publik yang patut dilindungi, sehingga dapat meningkatkan pembangunan di bidang sosial ekonomi dan teknologi. Ketentuan ini secara tidak langsung mencerminkan kriteria kepentingan umum dalam peruntukan HKI dan intervensi negara.

Kesembilan adalah ketentuan Pasal 8 UU No. 14/2001 yang mengatur tentang jangka waktu perlindungan paten. Pasal 8 UU No. 14/2001 menentukan bahwa paten diberikan untuk jangka waktu selama 20 (dua puluh) tahun terhitung sejak tanggal penerimaan dan jangka waktu itu tidak dapat diperpanjang. Ketentuan ini sejalan dengan ketentuan Article 32 TRIPs. Setelah berakhirnya masa perlindungan paten ini, maka teknologi yang ada menjadi milik publik (public domain). Dengan berakhirnya perlindungan paten, maka bertambah invensi dan teknologi yang menjadi domain publik. Secara tidak langsung ketentuan ini mencerminkan kriteria kepentingan umum dalam hal peruntukan HKI bagi masyarakat dan negara.

Jika melihat tujuan dan prinsip-prinsip yang terdapat dalam TRIPs dan ketentuanketentuan dalam UU No. 14/2001, sekilas dapat disimpulkan bahwa secara normatif terdapat adanya keseimbangan pengaturan antara kepentingan perlindungan hak eksklusif pemegang paten dan kepentingan perlindungan pengguna paten dan kepentingan publik. Namun tidak

50 Pasal 118 Ayat (1) UU No. 14/2001.

51 M. Hawin,Intellectual Property on Parallel Importation. Yogyakarta: Gadjah Mada University Press, 2010, h. 272.

52 Ibid, h. 272-275. 
dipungkiri bahwa dalam pelaksanaannya prinsip keseimbangaan ini masih jauh dari yang diharapkan. ${ }^{53}$ Jika asas keseimbangan telah menjiwai TRIPs, maka sekitar sembilan juta orang di negara berkembang mungkin tidak harus mengalami kematian yang mengenaskan karena penyakit-penyakit menular. Hal ini terjadi karena tidak terjangkaunya harga obatanobatan. ${ }^{54}$ Bahkan dikatakan bahwa TRIPs adalah perjanjian yang paling kontroversial dalam WTO, karena ketentuan-ketentuan Paten telah dikaitkan dengan biaya perawatan kesehatan yang meningkat, biaya yang sulit dijangkau oleh negara-negara berkembang. ${ }^{55}$

Interaksi antara perdagangan dan HKI serta akses pada obatan-obatan telah menyebabkan penerimaan terhadap Deklarasi Doha tentang Perjanjian TRIPs dan Kesehatan Publik tahun 2001 (Doha Ministerial Declaration on the TRIPS Agreement and Public Health), yang merupakan desakan dari kelompok delapan puluh negara, yang dipimpin oleh Kelompok Afrika, Brazil, dan India. ${ }^{56}$ Deklarasi ini menegaskan bahwa perjanjian TRIPS harus diinterpretasikan dan dilaksanakan dengan cara yang memungkinkan negara-negara untuk mengambil langkah-langkah melindungi kesehatan publik dan mengedepankan akses pada obat-obatan. Salah satunya adalah melalui impor paralel. Oleh karena itu Perjanjian TRIPs tidak dapat digunakan untuk menentang kebijakan yang membolehkan impor paralel terhadap obat-obatan yang penting. ${ }^{57}$ Namun pada akhirnya, negara-negara berkembang gagal untuk memastikan Amerika Serikat mendukung persetujuan yang mengikat secara hukum.

53 Banyak pembahasan mengenai keberlakuan lisensi wajib (compulsory licensing) dalam praktik, antara lain oleh Ms. Sumana Chatterjee, Flexibilities Under Trips [Compulsory Licensing]:The Pharmaceutical Industry In India And Canada, SSRN: http://ssrn.com/abstract =1025386; Cameron Hutchison, Over 5 Billion Not Served: The TRIPS Compulsory Licensing Export Restriction, SSRN: http://ssrn.com/abstract =1012625; Peter K. Yu, TRIPS and Its Discontents, SSRN: http://ssrn.com/abstract = 578577; Hans Henrik Lidgard and Jeffery Atik Facilitating Compulsory Licensing under TRIPS in Response to the AIDS Crisis in Developing Countries, SSRN: http://ssrn.com/abstract $=794228$.

54 Lihat catatan kaki 8.

55 Peter Drahos, An Alternative Framework for the Global Regulation of Intellectual Property Rights, Austrian Journal of Development Studies, No. 1, October 2005, p.7., SSRN: http://ssrn.com/abstract =850751. Bandingkan, Thomas W. Pogge, Relational Conceptions of Justice: Responsibilities for Health Outcomes yang termuat dalam Sudhir Anand, Fabiene Peter, and Amartya Sen (Editors), Public Health, Ethics, and Equity, Oxford University Press, 2004, pp.135-159, yang salah satu pandangannya mengenai keadilan berkaitan dengan kesehatan adalah bahwa kekuatan pertimbangan-pertimbangan moral untuk mencegah dan mengurangi kondisi-kondisi medis tidak hanya bergantung pada faktor-faktor yang bersifat distribusi, seperti bagaimana parahnya orang-orang yang terpengaruh oleh kondisi-kondisi ini dalam jangka waktu yang absolut dan relatif, berapa biaya yang diperlukan untuk pencegahan dan penanganan dan berapa banyak pasien yang merasakan manfaat dari pengobatan tertentu. Namun itu juga bergantung pada faktor-faktor yang bersifat relasional, yaitu bagaimana keterkaitan kita dengan kondisi-kondisi medis yang diderita mereka. Berdasarkan faktor-faktor relational, menurut Pogge, negara maju juga bertanggung jawab atas kondisi-kondisi kesehatan di negara-negara berkembang jika negara-negara maju tersebut berkontribusi dalam menciptakan kondisi-kondisi tersebut. h..135,139-140.

56 Susan K. Shell, Private Power, Public Law The Globalization of Intellectual Property Rights, Cambridge: Cambridge University Press, 2003, h. 160.

57 Alan .O. Sykes, "Public Health and International Law: TRIPs, Pharmaceuticals, Developing Countries, and the Doha Solution”, (2002) 3 Chi.J. Int'1 L. 47, h. 54. Lihat juga Carolyn Deere. The Implementation Game The TRIPs Agreement and The Global Politics of Intellectual Property Reform in Developinng Countries, h. 127. 
Deklarasi Doha hanya menghasilkan pemberian perpanjangan penundaan berlakunya TRIPS bagi negara-negara tertinggal sampai dengan tahun $2016 .{ }^{58}$

\section{Kesimpulan}

Kepentingan umum dalam perlindungan paten memiliki justikasi secara normatif, konstitusional, dan filosofis. Justifikasi kepentingan umum dalam perlindungan paten didasarkan kepada kriteria kepentingan umum dalam perlindungan HKI, yaitu kriteria intervensi negara, peruntukan paten, dan remunerasi yang layak. Kriteria kepentingan umum dalam perlindungan paten tercermin dalam ketentuan yang mengatur tentang lisensi wajib, jangka waktu perlindungan paten, persyaratan substantif (standard of patentability), pelaksanaan paten oleh pemerintah, pembatasan invensi yang tidak dapat diberikan paten, penggunaan non-komersial yang terkait dengan pendidikan, penelitian dan percobaan, dan persyaratan isi perjanjian lisensi.

\section{Daftar Bacaan}

\section{Buku}

Anand, Fabiene and Sen (eds), Public Health, Ethics, and Equity, Oxford University Press, 2004

Apeldoorn, Pengantar Ilmu Hukum. Cetakan Kesepuluh. Jakarta: Pradnya Paramita, 2001.

Barizah, Intellectual Property Implications on Biological Resources Indonesia 's Adoption of International Intellectual Property Regimes and the Failure to Adequately address the Policy Challenges in the Area of Biological Resources, Jakarta: Nagara, 2010.

Davies and Garnett, Moral Rights, Sweet \& Maxwell, 2010.

Drahos, A Philosophy of Intellectual Property. Sydney: Darmouth Publishing Company, 1996.

Hampstead, Introduction to Jurisprudence. 3th edition, Praeger Publisher, 1972.

Harsono, Hukum Agraria Indonesia, Sejarah Pembentukan Undang-Undang Pokok Agraria, Isi dan Pelaksanaannya. cetakan kesebelas. Jakarta: Djambatan,2007.

Hawin, Intellectual Property on Parallel Importation. Yogyakarta: Gadjah Mada University Press, 2010.

Kalo, Pengadaan Tanah Bagi Pembangunan Untuk Kepentingan Umum. Jakarta: Pustaka Bangsa Press, 2004.

Leiter, Objectivity in Law and Morals. Cambridge University Press, 1999.

Maskus, Intellectual Property Rights in the Global Economy.Washington: Institute For International Economics, 2000.

58 Susan K. Shell, Op.cit., h.161. 
Van Overwalle, 'Human Rights' Limitations in Patent Law'. Dalam W. Grosheide. ed.. Intellectual Property and Human Rights A Paradox. Oxford: Edwar Elgar Publishing Ltd, 2010.

Parlindungan, Bunga Rampai Hukum Agraria Serta Landeform. Bagian I. Bandung: Mandar Maju, 1994.

Rawls, A Theory of Justice, Revised Edition. Cambridge: The Belknap Press of Harvard university Press, 1999.

Schlicher, Licensing Intellectual Property: Legal, Business and Market Dynamics. Wiley Intellectual Property Series. John Wiley \& Sons, Inc., 1996.

Sen, The Idea of Justice. Penguin Book, 2009.

Shell, Private Power, Public Law The Globalization of Intellectual Property Rights.Cambridge: Cambridge University Press,2003.

Soerapati, Hukum Kekayaan Intelektual dan Alih Teknologi. Salatiga, UKSW, 1999.

Vaver and Bently, (eds) Intellectual Property in the New Millennium Essays in Honour of William R. Cornish. New York: Cambridge University Press, 2004.

\section{Makalah}

Afori, "Human Rights and Copyright: The Introduction of Natural Law Considerations into American Copyright Law." 14 Fordham Intell.Prop.Media \& Ent.L.J. 497, 2004.

Heller, "The Tragedy of Anti Commons: Property in Transition From Marx to Markets", 111 Harv. L. Rev. 3, 1998.

Love, "Recent examples of the use of compulsory licenses on patents." Knowledge Ecology International, 8 March 2007.

Sitorus, "Kepentingan Umum dalam Perlindungan Hak Kekayaan Intelektual (Kajian terhadap Hak Cipta, Paten, dan Perlindungan Varietas Tanaman)". Disertasi. Program Doktor, Program Studi Ilmu Hukum, Fakultas Hukum Universitas Airlangga, 2014.

\section{Laman}

Abbot, "The Doha Declaration on the TRIPS Agreement and Public Health: Lighting a Dark Corner at the WTO". http:// ssrn.com/abstract=1493725, diakses pada 5 Mei 2012.

Chander, Anupam \& Madhavi Sunder. "Is Nozick Kicking Rawls's Ass? Intellectual Property and Social Justice." UC Davis Legal Studies Research Paper Series Research Paper No. 108 May/2007. http://ssrn.com/abstract=982981, diakses tanggal $22 \mathrm{Mei}$ 2012.

Chatterjee, "Flexibilities Under Trips [Compulsory Licensing]: The Pharmaceutical Industry In India And Canada." http://ssrn.com/abstract =1025386diakses tanggal $23 \mathrm{Mei}$ 2012. 
Drahos, "An Alternative Framework for the Global Regulation of Intellectual Property Rights." Forthcoming publication in Austrian Journal of Development Studies. http://ssrn.com/abstract $=850751$ diakses tanggal 22 Mei 2012.

--------“Expanding Intellectual Property's Empire: the Roleof FTAs.” www.bilaterals.org/ IMG/doc/Expanding_IP_Empire_-_Role_of_FTAs.doc, diakses tanggal 22 Mei 2012.

King, Chilton and Roberts, "Reflection on Defining the Public Interest" http://m.aas.sagepub.com/content/41/8/954.abstract, diakses tanggal21 Juli 2012.

Sahai, 'The Bogus Debate on Bioethics, Biotechnology and Development Monitor. March 1997, AbBioWorld. http://www.agbioworld.org/biotech-info/articles/biotech-art/bogus.html., diakses tgl. 22 Mei 2012. 